\title{
Current patterns, habitat discontinuities and population genetic structure: the case of the kelp Laminaria digitata in the English Channel
}

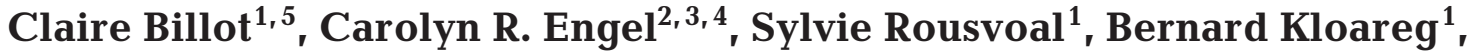 \\ Myriam Valero ${ }^{2,3,4, *}$ \\ ${ }^{1}$ UMR 1931 (CNRS and Laboratoires Goëmar S.A.), Station Biologique de Roscoff, 29682 Roscoff Cedex, France \\ ${ }^{2}$ Laboratoire de Génétique et Evolution des Populations Végétales, CNRS UPRESA 8016, GDR 1002, FR 1818, \\ Université de Lille 1, Bâtiment SN2, 59655 Villeneuve d'Ascq Cedex, France \\ ${ }^{3}$ CEOBM CNRS-UPMC UMR 7127, Equipe EGPM, Station Biologique de Roscoff, BP 74, 29682 Roscoff Cedex, France \\ ${ }^{4}$ Present address: CEOBM CNRS-UPMC UMR 7127, Equipe EGPM, Station Biologique de Roscoff, BP 74, 29682 Roscoff \\ Cedex, France \\ ${ }^{5}$ Present address: Biotrop, CIRAD/AMIS, TA 40/03, Avenue d'Agropolis, 34398 Montpellier Cedex 05, France
}

\begin{abstract}
Laminaria digitata is the dominant species of the dense, continuous kelp stands in the English Channel and on the Atlantic coasts of France, where it is harvested for its high quality alginates. However, in spite of its ecological and economic importance, our knowledge of the level and organisation of genetic diversity in this species is scant. Here, using comprehensive hierarchical sampling and 7 microsatellite loci, we explored the roles of dispersal strategies, current regimes and habitat discontinuities in shaping genetic structure of L. digitata populations. Our results show that continuous, non-fragmented forests of $L$. digitata were genetically differentiated at distances greater than $10 \mathrm{~km}$, despite the absence of clear population boundaries. Furthermore, a pattern of isolationby-distance indicated that gene flow occurred preferentially among adjacent populations following a stepping-stone model. In addition, we analysed the direction of migration using assignment tests and found that currents appeared to play a minor role in orienting gene flow, except in the Gulf of Saint Malo gyre. In contrast, habitat discontinuities were found to accentuate genetic differentiation and resulted in reduced genetic variation of isolated stands. In the context of a potential over-exploitation of kelp stands in Brittany, this study suggests that the existence of neighbouring populations can be vital to maintaining high levels of gene flow and thus, genetic diversity in this species.
\end{abstract}

KEY WORDS: Seaweed · Fragmentation · Hydrodynamic models · Dispersal $\cdot$ Asymmetric gene flow · Assignment test

Resale or republication not permitted without written consent of the publisher

\section{INTRODUCTION}

Genetic differentiation is generally associated with dispersal mode. In marine animals, numerous studies have demonstrated that the existence of a pelagic phase-promoting dispersal over long distancesstrongly influences genetic differentiation (for reviews, see Palumbi 1994, Bohonak 1999, Féral 2001). Indeed, in species with direct development, genetic differentiation occurs at smaller spatial scales than in species with planktonic larval phases (gastropods: Kyle \& Boulding 2000; marine shore fishes, Waples 1987; bryozoans: Goldson et al. 2001; echinoids: Poulin \& Féral 1996). Most marine algae are characterised by relatively short-lived spores and gametes (Santelices 1990). However, although they lack the strict equivalent of 'planktonic larvae' as in benthic invertebrates, drifting (detached) fertile thallus fragments occasionally constitute a mechanism for long-distance dispersal and reinforce gene flow. Although less abundant in comparison to benthic invertebrates, studies of genetic structure in seaweeds have effectively shown that genetic differentiation occurs at relatively short distances $(<1 \mathrm{~m}$ to $<10 \mathrm{~km})$ and that different modes of spore 
and/or gamete dispersal resulted in different levels of genetic structure (Sosa \& Lindstrom 1999, Valero et al. 2001). Indeed, in brown seaweeds, the few published population genetic studies suggest that species without floating dispersal stages show greater genetic structuring than species possessing such a stage (Lu \& Williams 1994, Williams \& Di Fiori 1996, Coyer et al. 1997, Kusumo \& Druehl 2000, Engelen et al. 2001).

The intensity of restricted gene flow also depends on the geographic relationships between source and recipient populations. In particular, genetic differentiation should increase with geographic distance when migration is spatially restricted, as predicted under a stepping-stone model (Kimura \& Weiss 1964). Thus, if dispersal is limited, isolation by distance will be detected even within continuously distributed populations. Furthermore, gene flow can be influenced by marine currents and/or discontinuities in the habitat. Genetic differentiation may not solely depend on geographic distance, but also on the orientation of currents, which can promote or prevent gene flow (rockfish: Rocha-Olivares \& Vetter 1999; marine invertebrates: Wares et al. 2001; brown seaweeds: Miller et al. 2000, Engelen et al. 2001). Discontinuities in the habitat, such as river mouths, stretches of unsuitable substrate etc., can also create barriers to gene flow and favour genetic differentiation (fishes: Bernardi 2000, Riginos \& Nachman 2001; snail: Johnson \& Black 1998a; red alga: Faugeron et al. 2001).

Kelps (order Laminariales, Phaeophyta) are the most abundant algae in the subtidal euphotic zone of rocky coasts, from temperate to polar seas. Present only on the western coast in the North Atlantic, Laminaria digitata is the dominant species of the dense and continuous kelp stands on the English Channel and Atlantic coasts of France (Kain 1979). These large brown seaweeds are ecologically important in coastal environments as primary producers, important contributors to food webs and as shelters to a wide range of invertebrates (Duggins et al. 1989, Norton et al. 1996, Walker $\&$ Kendrick 1998). Kelps are not only important ecosystem engineers (Kain 1979, Coleman \& Williams 2002), but they are also a main marine commercial resource for various (e.g. food, cosmetic and paint) industries as a source of gel-forming polysaccharides, known as alginates. In Brittany, natural populations of L. digitata are harvested for their high quality alginates (Arzel 1998). However, monitoring the production of L. digitata in Brittany over the past $15 \mathrm{yr}$ has shown that despite increased harvesting capacities, the annual landings of $L$. digitata have been decreasing over the past 5 yr (Arzel 1998, P. Arzel pers. comm.).

In spite of its ecological and economic importance, our knowledge of the genetic resources in Laminaria digitata is scant. In particular, since boundaries among populations are difficult to discern, it is not known whether the L. digitata forest forms a single genetic entity or several genetically differentiated entities. This question is especially important in light of potential over-exploitation of L. digitata stands. In this study, we used 7 microsatellite loci (Billot et al. 1998) to examine the pattern of genetic diversity in stands of L. digitata on the North Atlantic coast and in the English Channel. Using a hierarchical sampling design (from $45 \mathrm{~m}$ to $>100 \mathrm{~km}$ ), we aimed to assess the effective dispersal abilities of L. digitata and to determine the geographic scale at which differentiation occurs. First, we explored the genetic diversity at the smallest sampling scale to examine whether mating occurs at random. Second, by comparing genetic distance with geographic distance, we compared the differentiation among the hierarchical scales and confronted this differentiation with an isolation-by-distance model. Third, we assessed the role of tidal currents and habitat discontinuities in the observed differentiation pattern. Finally, we tested the possibility of directional, current-oriented gene flow using an assignment test.

\section{MATERIALS AND METHODS}

Study species. Laminaria digitata is a short-lived perennial species characterised by a heteromorphic haploid-diploid life cycle (Sauvageau 1916), in which diploid sporophytes alternate with haploid gametophytes. The large, conspicuous plants (up to $3 \mathrm{~m}$ long) belong to the diploid sporophyte generation. These sporophyte plants produce large numbers of meiospores (zoospores), which after a planktonic stage lasting up to $72 \mathrm{~h}$, settle and grow into microscopic male and female gametophytes. These in turn produce gametes by mitosis. Male gametes are released and fertilise female gametes that are retained on the female gametophyte. Following fertilisation, a new sporophyte plant develops. L. digitata meiospores are produced directly on the blade, the flag-like distal portion of the plant (i.e. 1 to $3 \mathrm{~m}$ above the substratum).

Male gamete dispersal is probably extremely limited (ca. $1 \mathrm{~mm}$; Maier et al. 1988) as spermatozoids are incited to release by the pheromones produced by female gametophytes (Müller et al. 1979). Kelp dispersal is thus ensured mainly by planktonic bi-flagellate haploid spores or possibly by drifting fertile thallus fragments that continue to produce and release meiospores.

As the gametophytes are dioecious, outcrossing is obligatory. However, fertilisation between gametophytes arising from the same sporophyte, equivalent to self-fertilisation, is possible (Billot et al. 1999). Asexual or vegetative reproduction is not known in natura in 
kelps; however, asexual reproduction (apospory) has been successful in the laboratory (Le Gall et al. 1996).

Sampling. A total of 438 diploid individuals were sampled in 1997 and 1998, from natural, non-harvested areas along the coasts of Brittany and Normandy following a hierarchical design (Fig. 1A). In all, 18 plots were grouped into 12 sites (separated by ca. 10 to $50 \mathrm{~km}$ ) belonging to 4 regions. In 5 sites, 2 plots separated by less than $2 \mathrm{~km}$ were sampled. In each plot, 25 sporophytes were sampled within a $50 \mathrm{~m}^{2}$ area, except at NB-5 (Plougrescant), where only 13 sporophytes were collected. Sampling reflects the species' distribution in the study area. In particular, plots were sampled
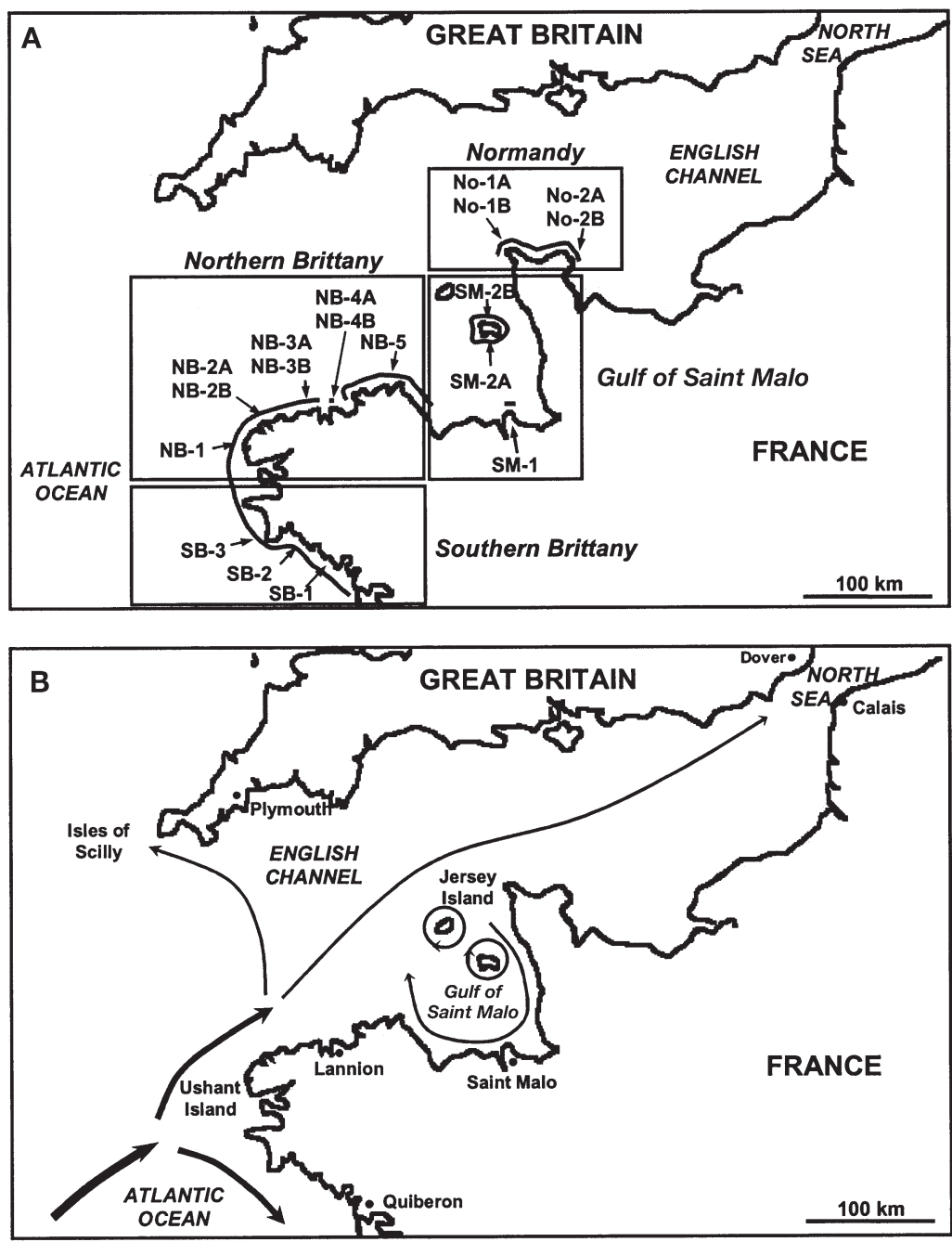

Fig. 1. Laminaria digitata. Geographic and hydrodynamic characteristics of sampled stands of L. digitata. (A) Locations of sampled plots along the coasts of Brittany and Normandy. The distribution of L. digitata stands in the study area is indicated by bold thick lines (Thouin et al. 1983, present study). (B) Long-term, average current trajectories in the English Channel, based on Salomon \& Breton (1993) and the French Service Hydrographique et Oceanographique de la Marine from the continuous stands of kelps in Brittany and Normandy and from isolated stands along the shoreline delimited by unsuitable sandy substrate, as for Locquirec (NB-4) and Saint Malo (SM-1), or by land discontinuities, as for the island of Jersey (SM-2) (Fig. 1).

Current patterns in the English Channel. Arriving at the western point of Brittany, the major current, the Gulf Stream, is diverted into 2 main orientations (Fig. 1B). South of Ushant Island, currents are characterised by south-bound flow; whereas north of Ushant Island, waters entering the English Channel present an eastern-orientated flow. These waters are diverted towards the north, and, according to Salomon \& Breton's tidal current model (no wind, average tidal amplitude), they follow a path off Lannion towards Plymouth (Fig. 1B; Salomon \& Breton 1993). The current then separates into 2 routes, 1 westbound along the Cornwall coast towards the Scilly Islands and the other eastbound towards Normandy. The remainder of the flow forms large gyres around the islands of Jersey and Guernsey, which delimit the Gulf of Saint Malo. Although this general pattern varies with wind and with other physical factors, the Gulf of Saint Malo is always isolated from the main flow (Salomon \& Breton 1993).

Microsatellite genotyping. The meristematic part of each thallus was cleaned of epiphytes and desiccated in silica gel until DNA extraction. DNA was extracted using Chelex (Biorad) beads according to Billot et al. (1998). Seven microsatellite loci (Ld1-124, Ld2148, Ld2-158, Ld2-167, Ld2-531, Ld2371 and Ld2-704) were amplified according to standard PCR protocols to genotype each individual thallus (Billot et al. 1998). Allele sizes and composition of each individual were determined using an automatic VISTRA sequencer (Molecular Dynamics) as described in Billot et al. (1998).

Data analysis. Genetic polymorphism in each plot was measured as the mean number of alleles per locus $\left(N_{\mathrm{a}}\right)$, gene diversity $\left(H_{\mathrm{e}}\right.$, sensu Nei 1978) and observed heterozygosity $\left(H_{0}\right)$ using the GENETIX software package (Ver. 4.01; Belkhir et al. 1999). Allele frequencies are available upon request. Fixation indices $\left(F_{\text {IS }}\right)$ within each plot were computed for each locus and heterozygote 
deficiencies and excesses were tested using 10000 randomisations of alleles among individuals within each plot using FSTAT (Goudet 1995).

Two-way analyses of variance (ANOVA) were performed on per-plot and per-locus $H_{\mathrm{e}}, N_{\mathrm{a}}$ and $F_{\mathrm{IS}}$ estimates to test for the congruence of the loci and to check the occurrence of panmictic reproductive systems in each plot. The factors plot and locus were declared random and both tested over the error term, as only 1 value was observed per locus and per plot, precluding an interaction term. Differences in gene diversities and mean number of alleles were assessed using a Wilcoxon 2 -sample test when comparing plots from continuously distributed stands and isolated stands.

To test for the genetic independence of the microsatellite loci, genotypic linkage disequilibria between the 21 pairs of loci were tested in each plot by performing 10000 permutations of alleles within a locus with GENETIX software (Ver. 4.01; Belkhir et al. 1999). The proportion of permutations as high as or higher than the observed value provides an unbiased estimation of the probability that there is no linkage disequilibrium. Sequential Bonferroni correction was applied to guard against Type I error when performing multiple tests (adjusted $5 \%$ nominal level $=0.26 \%$ ) (Rice 1989).

The organisation of genetic diversity was analysed using Weir \& Cockerham's (1984) estimators of $F$-statistics. In this analysis, $F_{\mathrm{IS}}$ estimates the average deviation from random mating within plots and $F_{\mathrm{ST}}$ the average differentiation between plots. Genetic differentiation was also estimated at the different scales of the hierarchical sampling. First, $F_{\mathrm{PS}}$ measures the differentiation between plots belonging to the same site; second, pooling plots within sites, $F_{\mathrm{SR}}$ measures differentiation between sites within a region; finally, pooling sites, $F_{\mathrm{RT}}$ measures the differentiation between regions. Values and their SDs (obtained by jack-knifing over loci) were computed using the FSTAT software package (Ver. 2.9.1; Goudet 1995). The significance of the deviation of each estimator from 0 was tested using the permutation procedure included in FSTAT (10 000 randomisations).

Isolation by distance (Slatkin 1993) was tested by regressing pairwise genetic distances on the geographical distances separating sites using GENEPOP (Ver. 3.1a; Raymond \& Rousset 1995). Genetic distances were measured as $F_{\mathrm{ST}} /\left(1-F_{\mathrm{ST}}\right)$, where $F_{\mathrm{ST}}$ is the multilocus estimate (Rousset 1997). Geographical distances were measured as distances along the coast for continental populations and taken as the direct distance for the Jersey site. Considering its limited bathymetric range (+1 to $-5 \mathrm{~m}$ ), Laminaria digitata occupies a habitat (rocky substrata along the coast) much longer than it is wide. We therefore considered that dispersal distances would be better equated to a linear (1-dimensional) distribution than a radial (2-dimensional) one (Rousset 1997); thus, linear, not log-transformed distances, were used. The correlation between matrices of genetic and geographic distances was tested using a Mantel permutation procedure (10 000 permutations) as provided in the GENEPOP software package, where the $p_{\text {Mantel }}$ value is the proportion of permutations resulting in a correlation coefficient equal to or less than the observed value.

Assignment tests. While genetic differentiation estimated by $F_{\mathrm{ST}}$ informs as to the degree of differentiation among populations, assignment tests are powerful methods for identifying (recent) immigration events, even when overall differentiation among populations is low (Rannala \& Mountain 1997, Waser \& Strobeck 1998). Assignment tests are particularly pertinent in exploring the role of marine currents in the genetic differentiation among populations as the patterns of misclassification can be used to determine the direction of migration. The probability that Laminaria digitata individuals are (recent) immigrants from sites other than the site of sampling (site of 'residence') was determined using the 'Bayesian' method provided in computer program GeneClass (Cornuet et al. 1999). This method is based on Rannala \& Mountain's (1997) approach that determines the likelihood of drawing a particular multilocus genotype from a resident and from a potential source site, based on the assumption that loci are independent. Individuals are assigned to the most likely population of those included in the study. All individuals are thus assigned to 1 population, whether it be the 'true' population of origin or one with the closest matching genetic signature (Cornuet et al. 1999).

Using all 12 sites, sites of residence and sites of assignment were confronted to evaluate the proportion of immigrants in each site and the origin of any immigrants. Unilateral Fisher exact tests were performed using BIOMstat Ver. 3.301 (Exeter software) to test: (1) differences in the rates of immigration between isolated and continuous stands; (2) differences in immigration and emigration rates in isolated stands; and (3) orientation of gene flow in the Channel. More specifically, these hypotheses were tested as follows. First, since isolated stands by definition exchange fewer migrants with other populations, the proportion of individuals correctly classified within their site of origin should be higher in isolated stands compared to continuous stands. Second, if each isolated stand behaves as a sink (i.e. exports few migrants), the number of emigrants out of each isolated stand (i.e. individuals collected in Northern Brittany and Normandy, but assigned to isolated stands) should be greater than the number of immigrants into those stands (i.e. individuals sampled in each isolated stand, but assigned to Normandy or Northern Brittany). Third, if there is 
directional gene flow oriented from west to east in the Channel as predicted by Salomon \& Breton's (1993) model, the number of emigrants from Northern Brittany to Normandy should be greater than the number of immigrants from Normandy into Northern Brittany.

\section{RESULTS}

\section{Genetic diversity and Hardy-Weinberg equilibrium in Laminaria digitata populations}

Numbers of alleles and gene diversity are given for each microsatellite locus and for each population in Table 1. Generally, genotypes could be determined for virtually all individuals and microsatellite loci with the exception of Locus Ld2-158, which, due to poor amplification, was undersampled in 3 populations. The number of alleles per locus ranged from 6 to 23. Mean numbers of alleles were significantly different between plots and loci (2-way ANOVA without replication, locus, $F_{6,102}=77.63, \mathrm{p}<0.001$; plot, $F_{17,102}=3.87$, $\mathrm{p}<0.001)$. Mean gene diversity varied significantly between loci (from 0.43 to 0.85 ; Table 1), but showed only marginal differences between plots (2-way ANOVA without replication: locus, $F_{6,102}=36.11, \mathrm{p}<0.001$; plot, $F_{17,102}=1.97, \mathrm{p}=0.07$ ). Most alleles (46 out of a total of 72 alleles) were shared among Atlantic and English Channel populations, with none of them being diagnostic for the Atlantic populations.

Only 1 pair of loci (i.e. $0.3 \%$ ) showed significant linkage disequilibrium, suggesting that, in general, loci segregate independently. The lone detected locus pair in linkage disequilibrium was due to the correlation between rare alleles of Loci Ld2-158 and Ld2-167 observed in 2 individuals of the NB-2B site.

The multilocus $F_{\text {IS }}$ estimated over the 18 sites was low, but significant $\left(F_{\mathrm{IS}}=0.07 ; \mathrm{SD}=0.016 ; \mathrm{p}<0.001\right)$. This positive value indicated a slight heterozygote deficiency. However, over the $156 F_{\text {IS }}$ values calculated for each locus and plot, only 4 remained significant after Bonferroni correction (Table 1 ). $F_{\text {IS }}$ values did not vary significantly among loci and plots (2-way ANOVA without replication: locus, $F_{6,102}=1.45, \mathrm{p}=0.20$; plots, $F_{17,102}=$ $0.86, \mathrm{p}=0.62)$. Finally, only 1 plot (SM-2B, Jersey) exhibited a significant multilocus $F_{\text {IS }}$ value $(0.19, \mathrm{p}<0.05)$.

\section{Patterns of genetic differentiation in Laminaria digitata populations}

Hierarchical analysis

The multilocus $F_{\mathrm{ST}}$ estimated using all 18 sites was highly significant, indicating that gene flow is limited in Laminaria digitata $\left(F_{\mathrm{ST}}=0.068 ; \mathrm{SD}=0.011\right.$; $\mathrm{p}<0.001)$. Hierarchical analysis revealed similarities in genetic differentiation among the 4 regions. At the lowest level of the hierarchical sampling, the low, nonsignificant estimates of $F_{\text {PLS }}$ established that plots within sites were not genetically distinct, whatever the region. At the between-sites/within-region level, $F_{\mathrm{SR}}$ values were systematically greater than $F_{\mathrm{PL}}$ values and highly significant, showing a pattern of concomitant increase in genetic and geographic distances (Fig. 2). However, the degree of differentiation varied among regions. At distances of 10 to $50 \mathrm{~km}$, Southern Brittany and Normandy showed differentiation $\left(F_{\text {SR }}\right)$ weaker than that observed at 50 to $100 \mathrm{~s}$ of $\mathrm{km}\left(F_{\mathrm{RT}}\right)$ (Fig. 2). On the other hand, the $F_{\mathrm{SR}}$ values within Northern Brittany and the Gulf of Saint Malo regions were actually greater than that of the overall differentiation among regions $\left(F_{\mathrm{RT}}\right)$. These latter 2 regions both contain isolated stands (Gulf of Saint Malo: Sites SM1 and SM2; Northern Brittany: Site NB4). In addition, these isolated stands exhibited a significantly lower genetic diversity than sites sampled within the continuously distributed stands (isolated: $N_{\mathrm{a}}=5.00, H_{\mathrm{e}}=0.529$; continuous: $N_{\mathrm{a}}=5.43, H_{\mathrm{e}}=0.596$; Wilcoxon 2-sample test: $N_{\mathrm{a}}, \mathrm{p}=0.009$ and $H_{\mathrm{e}}, \mathrm{p}=0.04 ;$ Plougrescant [NB5] excluded from calculations due to insufficient sample size).

\section{Isolation by distance}

An overall pattern of isolation by distance was present (regression equation: $F_{\mathrm{ST}} /\left[1-F_{\mathrm{ST}}\right]=5 \times 10^{-5} \mathrm{D}+$ $0.063, \mathrm{R}^{2}=0.034, p_{\text {Mantel }}=0.016$, where $\mathrm{D}$ is geographic distance). First, a clear pattern was present for sites of the continuous stands from Southern Brittany, Northern Brittany and Normandy (regression equation: $F_{\mathrm{ST}} /\left[1-F_{\mathrm{ST}}\right]=7 \times 10^{-5} \mathrm{D}+0.027, \mathrm{R}^{2}=0.504$, $p_{\text {Mantel }}=0.006 ;$ Fig. 3), suggesting that the genetic structure of these sites results from an equilibrium between genetic drift and distance-restricted migration. The relatively weak slope of the regression curve indicates that levels of gene flow were nevertheless high. Among the isolated stands ( $\square$, Fig. 3), Locquirec (NB-4) and Saint Malo (SM-1) were greatly differentiated from all other sites $\left(F_{\mathrm{ST}}\right.$ estimates ranged from 0.08 to 0.16 ; details not shown). As for Jersey, differentiation between the Jersey (SM-2) and Brittany (Northern and Southern) sites fit the clear BrittanyNormandy isolation-by-distance pattern ( $\square$ found in proximity of regression line, Fig. 3), while the differentiation between Jersey (SM-2) and Normandy was greater than expected from the isolation-by-distance pattern established using the continuous BrittanyNormandy stands. 


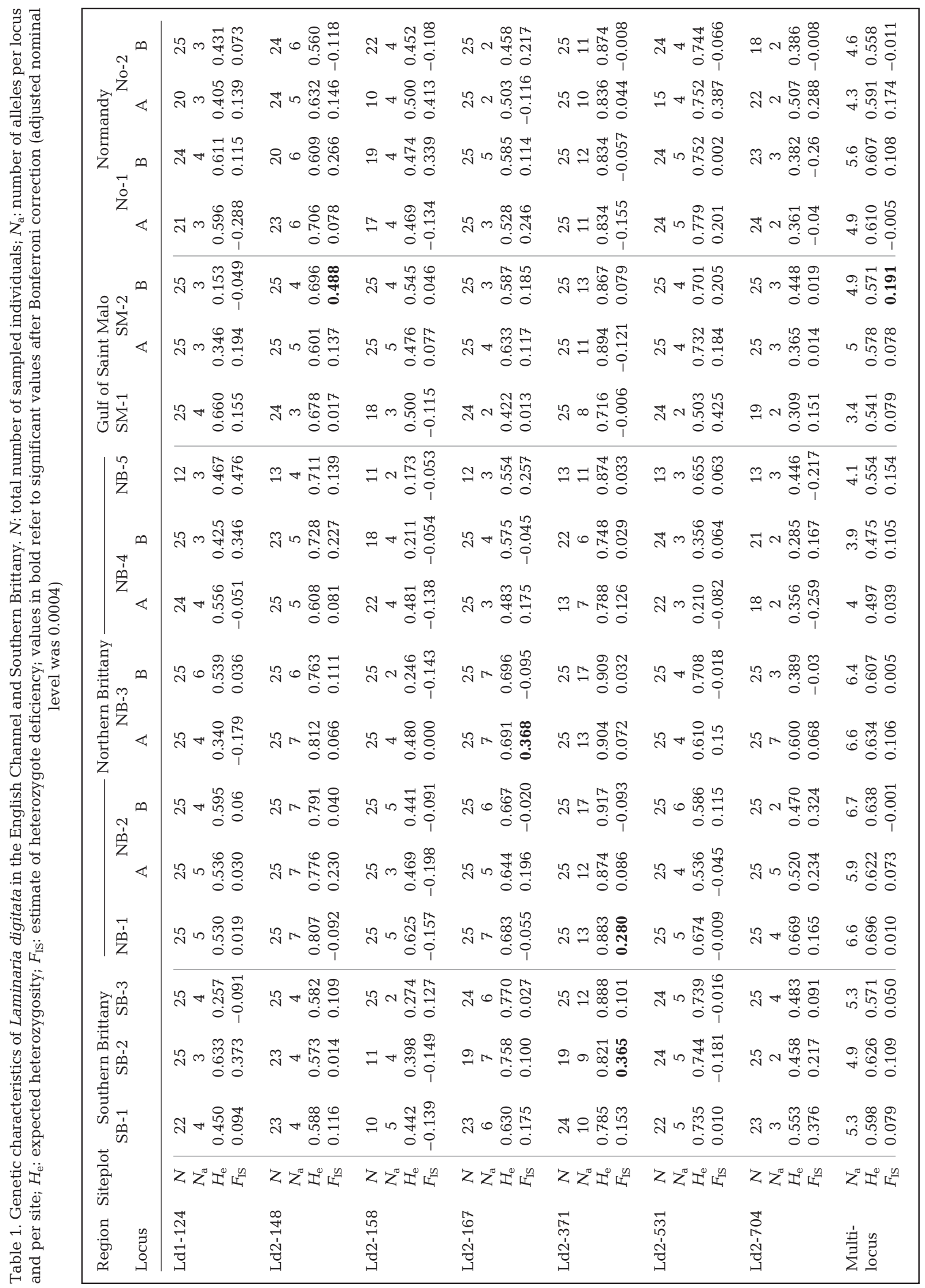




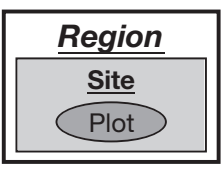

$F_{\mathrm{RT}}=0.042 * \star *$

Fig. 2. Laminaria digitata. Hierarchical genetic differentiation of $L$. digitata populations. $F_{\mathrm{PS}}$ : differentiation between plots within sites; $F_{\mathrm{SR}}$ : differentiation between sites within a region; $F_{\mathrm{RT}}$ : differentiation between regions. ${ }^{* *}$ and *** refer to significant values with $\mathrm{p}<0.01$ and $\mathrm{p}<0.001$, respectively, corrected by a Bonferroni test over sites in regions and plots in sites
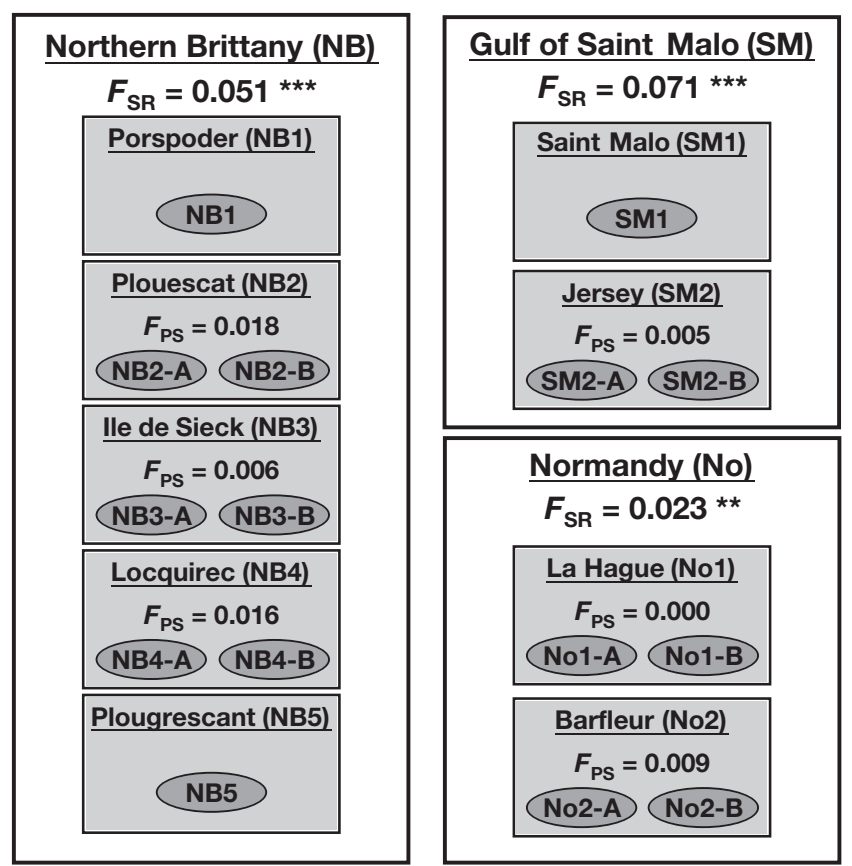

\section{Assignment tests}

Individuals from the 12 sites were classified according to site of origin (sampling) and site of assignment (Table 2). Overall, the individuals coming from isolated sites (Locquirec: NB-4; Saint Malo: SM-1; Jersey: SM-2) were significantly better assigned to their site of residence than those sampled in continuous stands: in isolated stands, we observed 93 correctly assigned individuals out of the 125 collected individuals (74\%); while in continuous stands, the ratio was $143: 313$ (46\%) (93:32 vs 143:170; Fisher exact test, $\left.\mathrm{p}=3 \times 10^{-8}\right)$. Moreover, isolated stands tended to have higher rates of immigration than emigration from/to the neighbouring Northern Brittany and Normandy regions (SM-1: $\mathrm{p}=0.031 ;$ SM-2: $\mathrm{p}=0.053 ; \mathrm{NB}-4: \mathrm{p}=0.020 ;$ adjusted $5 \%$ nominal level $=0.017$ ).

Among continuous stands, a relatively high level of gene flow was detected among regions: 9 to $15 \%$ of migrants were detected between the central region (Northern Brittany) and its 2 neighbouring regions (Southern Brittany and Normandy). Moreover, no pattern of current-oriented gene flow could be observed in the English Channel, since as many migrants arrived from Normandy as were sent there: 14 migrants from Normandy were collected among the 138 Northern Brittany plants (10\%) and 15 out of 100 individuals collected in Normandy were identified as migrants from Northern Brittany $(15 \%)(\mathrm{p}=0.176)$.

Interestingly, among the isolated stands, the Gulf of Saint Malo sites (SM-1 and SM-2) appeared to receive more migrants from Northern Brittany than from Nor- mandy, with Saint Malo receiving no migrants from Normandy. More strikingly, no exchange at all existed between the 2 Gulf of Saint Malo sites. Similarly, Locquirec (NB-4) did not receive any migrants from Normandy and most of the gene flow came from the Northern Brittany region.

\section{DISCUSSION}

In this study, 7 microsatellite loci revealed 72 alleles within 438 diploid Laminaria digitata genomes. This

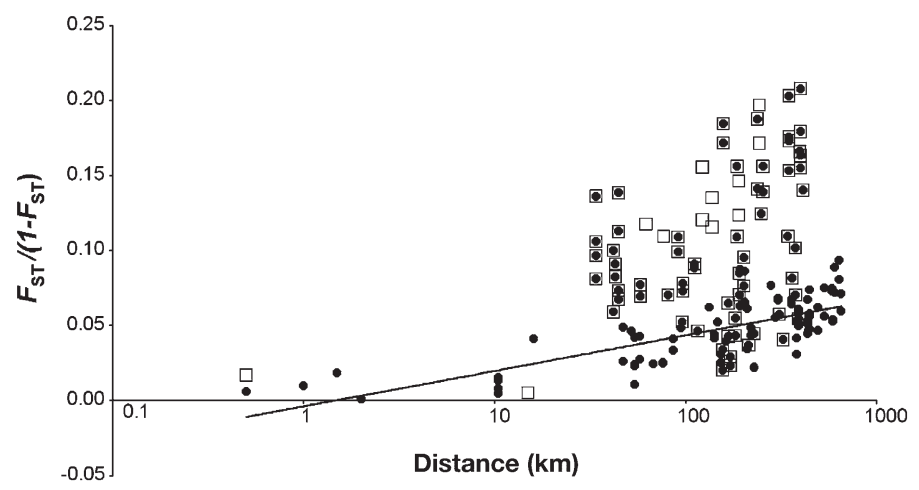

Fig. 3. Laminaria digitata. Genetic differentiation of L. digitata populations in the English Channel. Pairwise genetic distances, represented as $F_{\mathrm{ST}} /\left(1-F_{\mathrm{ST}}\right)$, are plotted against geographic separation distances. $(\bullet)$, Pairs of sites found in continuous stands; (), pairs of sites sampled in isolated stands; ( $\square$ ) pairs consisting of a continuous-stand site and an isolated-stand site 
Table 2. Number of individuals assigned to each of the studied sites

\begin{tabular}{|c|c|c|c|c|c|c|c|c|c|c|c|c|}
\hline \multirow[b]{2}{*}{ Observed site } & \multirow[b]{2}{*}{ SB1 } & \multirow{2}{*}{$\begin{array}{l}\text { SB } \\
\text { SB2 }\end{array}$} & \multirow[b]{2}{*}{ SB3 } & \multicolumn{4}{|c|}{ Brittany-Normandy continuum - } & \multirow{2}{*}{$\overline{\text { No1 }}$} & $-\mathrm{No}-$ & \multicolumn{3}{|c|}{ — Isolated stands - } \\
\hline & & & & NB1 & NB2 & NB3 & NB5 & & No2 & NB4 & SM1 & SM2 \\
\hline \multicolumn{13}{|l|}{ Predicted site } \\
\hline SB1 & 13 & 6 & 1 & 0 & 3 & 0 & 0 & 1 & 0 & 0 & 0 & 2 \\
\hline SB2 & 4 & 12 & 2 & 1 & 0 & 0 & 0 & 0 & 0 & 1 & 0 & 0 \\
\hline SB3 & 1 & 3 & 10 & 2 & 1 & 5 & 1 & 0 & 0 & 3 & 0 & 5 \\
\hline NB1 & 1 & 1 & 1 & 13 & 3 & 2 & 0 & 2 & 1 & 0 & 0 & 1 \\
\hline NB2 & 0 & 0 & 2 & 2 & 22 & 11 & 0 & 4 & 3 & 2 & 0 & 3 \\
\hline NB3 & 1 & 0 & 1 & 1 & 9 & 14 & 2 & 3 & 1 & 0 & 1 & 2 \\
\hline NB5 & 1 & 0 & 3 & 0 & 2 & 1 & 5 & 1 & 0 & 4 & 2 & 0 \\
\hline No1 & 1 & 2 & 0 & 1 & 2 & 3 & 1 & 21 & 7 & 0 & 0 & 2 \\
\hline No2 & 2 & 0 & 2 & 1 & 3 & 3 & 0 & 13 & 33 & 0 & 0 & 1 \\
\hline NB4 & 0 & 1 & 1 & 2 & 0 & 2 & 1 & 1 & 2 & 38 & 0 & 1 \\
\hline SM1 & 0 & 0 & 1 & 0 & 1 & 1 & 2 & 1 & 0 & 0 & 22 & 0 \\
\hline SM2 & 1 & 0 & 1 & 2 & 4 & 8 & 1 & 3 & 3 & 2 & 0 & 33 \\
\hline \multirow{2}{*}{ Total observed } & $\underline{25}$ & 25 & 25 & 25 & 50 & 50 & 13 & 50 & 50 & 50 & 25 & 50 \\
\hline & & 75 & & \multicolumn{4}{|c|}{138} & \multicolumn{2}{|c|}{100} & & & \\
\hline
\end{tabular}

high level of genetic diversity allowed not only the analysis of population structure, but also the precise identification of migration events between populations and the direction of this migration. We have shown that, despite the absence of clear boundaries between populations, Laminaria digitata populations are geographically structured. Discussed below are 3 possible causes that may have generated the observed pattern of genetic diversity in and among $L$. digitata populations: (1) intrinsic life history characteristics, (2) current patterns and (3) habitat discontinuities.

\section{Mating system and genetic differentiation: inferring dispersal patterns}

Given the haploid-diploid life cycle of kelps, consanguineous mating or genetic sub-structuring can only arise from limited spore dispersal and the subsequent preferential mating between neighbouring (sibling) gametophytes. The present study suggests that most matings occurred at random in Laminaria digitata stands of at least $50 \mathrm{~m}^{2}$, even if some inbreeding or spatial sub-structuring may occur in a given site (Table 1). Moreover, the consistency among loci and the absence of linkage disequilibrium showed that asexual reproduction is negligible in natural populations of L. digitata.

The hierarchical sampling design used in this study demonstrates that Laminaria digitata stands of at least $2 \mathrm{~km}$ constitute a single genetic entity, as plots were never significantly differentiated within sites. However, significant genetic structure was systematically observed between sites (separated by ca. 10 to $50 \mathrm{~km}$ ). At distances greater than $10 \mathrm{~km}$, even if episodic migration events (e.g. via drifting spore-bearing blades) may exist, they were not sufficient to prevent significant genetic differentiation in continuous nonfragmented stands. A clear pattern of increasing genetic distance with geographical distance revealed that gene flow, via the dispersal of spores, occurs preferentially among adjacent stands following a steppingstone (isolation-by-distance) model within continuous non-fragmented stands.

In benthic marine invertebrates, differences in levels of gene flow have been causally linked to the mode of larval dispersal (direct development vs planktonic larvae, e.g. Knowlton \& Jackson 1993, Poulin \& Féral 1996, Shulman 1998). Likewise, in kelps, differences in spore dispersal are expected depending on the morphology of the species (Dayton 1985). Some stipate and prostate species such as Macrocystis ssp. and members of the Alariaceae family have sprorophylls at the base of the plant near the substratum which probably promotes only limited dispersal. Similarly, the sea-palm kelp, Postelsia palmaeformis, is characterised by drooping, deeply grooved blades which favour local recruitment by channelling and concentrating zoospores near the parental sporophyte. On the contrary, some other species, such as Pelagophycus porra and Laminaria digitata form sori at the distal end of the thallus which are far above the substratum, favouring wider spore dispersal. Differences in levels of genetic structure confirmed the difference in dispersal distances between the 'proximal' and 'distal' spore dispersal strategies. The use of dominant fingerprint-type genetic markers (M13, RAPD, AFLP) have shown limited spore dispersal by revealing strong significant genetic structuring at fine spatial scales in 2 species characterised by 'proximal' dispersal (Alaria margi- 
nata, $<15$ m, Kusumo \& Druehl 2000; P. palmaeformis, $<25 \mathrm{~m}$, Coyer et al. 1997). In comparison, meiospores of 2 'distal' strategy species (P. porra, Miller et al. 2000; $L$. digitata, the present study) disperse at distances in the order of $\mathrm{km}$ since significant genetic differentiation was not revealed at this scale $(20 \mathrm{~km}$ in 'leeward' $P$. porra; $2 \mathrm{~km}$ in L. digitata).

\section{Genetic structure and current patterns}

In addition to the intrinsic dispersal strategy adopted by Laminaria digitata, the hydrodynamic features of the English Channel and the North Atlantic coasts of France may also shape gene flow. The dispersive properties of the currents in the English Channel, a sea featuring some of the greatest tidal amplitudes and strongest currents in the world, have been described in detail by hydrodynamic models of residual tidal currents (Salomon \& Breton 1993), and applied to the dissemination of particles (Guegueniat et al. 1993) and larvae (e.g. Thiébaut et al. 1994, 1996, Barnay et al. 2003, Ellien et al. unpubl.). The existence of such a model provides a valuable opportunity to compare genetic differentiation patterns with the comprehensive information on current dynamics in Brittany and Normandy.

Using major current trajectories (Fig. 1B) to formulate hypotheses on the directionality of gene flow, offshore gene flow (i.e. between Northern Brittany and the Gulf of Saint Malo) showed the expected asymmetry: currents did orient gene flow in the Gulf of Saint Malo, effectively isolating Jersey (SM-2) and Saint Malo (SM-1) from Normandy (No-1 and No-2). However, our results reveal that currents play a relatively minor role in shaping genetic differentiation patterns of continuous coastal kelp populations. In particular, gene flow occurred among Southern Brittany and Northern Brittany Laminaria digitata stands in a stepping-stone fashion in spite of differences in current orientation between the English Channel and the Atlantic. Moreover, assignment tests confirmed that exchanges occurred in both directions, across the divergent currents. Furthermore, within the English Channel itself, no pattern of current-oriented gene flow was observed, since no predominant easternoriented flow could be detected.

While significant surface currents have been shown to shape patterns of genetic differentiation in some species (e.g. seagrass: Bandeira \& Nilsson 2001; bryozoans: Goldson et al. 2001; fish: Rocha-Olivares \& Vetter 1999), other studies have found no correlation (echinoderms: Palumbi et al. 1997; reef fishes: Shulman \& Bermingham 1995). In this study, 2 major reasons may explain the absence of current/gene flow correlation of Laminaria digitata in the English Channel. First, even though it accurately describes gene flow between mainland and island populations, Salomon \& Breton's (1993) model does not take into account the local turbulence regimes independent from main current trajectories created by the convoluted topography of the Brittany coast. Second, currents in the English Channel are highly dependent on wind conditions and are thus variable in time (Salomon \& Breton 1993), either in intensity or even in orientation. Interestingly, however, in Salomon \& Breton's (1993) model, the isolation of the Gulf of Saint Malo prevails whatever the wind conditions. Altogether, our results indicate that currents shape gene flow in kelp populations only when the major trajectories depend on neither local topography nor variable wind conditions.

\section{Habitat discontinuities}

Natural population discontinuities occur if the rocky substratum required for settlement of Laminaria digitata gametophytes is interrupted. Indeed, while we have shown the importance of current regimes in assuring the connection of the Jersey (SM-2) site with the Brittany continuum, Jersey nevertheless showed reduced genetic variability. Lower genetic diversity and comparatively fewer alleles were also featured in 2 other sites located in isolated stands, Locquirec (NB-4) and Saint Malo (SM-1). Thus, as predicted (see Young et al. 1996), fragmentation in species that otherwise occur naturally in large, continuous populations, generally leads to a reduction in genetic variation (Templeton et al. 1990, Young et al. 1996, 1999). This reduction arises from either a bottleneck (reduction in census population size) or from the rupture of connection with other populations (reduction in gene flow) (Young et al. 1996, Templeton 1998).

In this study, the 3 isolated sites were much more differentiated from the other sites than would be predicted by the isolation-by-distance pattern modelled on continuous stands. This increase in genetic differentiation suggests that the reduction in genetic variation in isolated sites results from reduction in gene flow with neighbouring Laminaria digitata stands. Indeed, in other marine species, habitat discontinuities accentuate genetic differentiation (fish: Danley et al. 2000, Riginos \& Nachman 2001; red alga: Faugeron et al. 2001; marine gastropod: Johnson \& Black 1998b; squid: Shaw et al. 1999). Thus, in spite of the highly dispersive nature of the marine environment, the existence of neighbouring populations can be vital to maintaining high levels of gene flow. 


\section{Implications for the harvesting Laminaria digitata populations}

We have shown that the continuity of kelp stands was more important for gene flow than hydrodynamic regimes in 2 ways. First, we demonstrated an isolationby-distance pattern of genetic differentiation between Southern and Northern Brittany in spite of divergent, potentially isolating, currents. Second, we revealed that habitat discontinuities accentuate genetic differentiation and, consequently, reduce genetic variation. Artificial fragmentation of Laminaria digitata populations is thus likely to reduce genetic variation in natural populations by rupturing contacts with neighbouring stands. Although the link between reduction in neutral genetic diversity and extinction is debated (Schemske et al. 1994), new harvesting practices may lead to the fragmentation of continuous populations beyond demographic sustainability. In the context of possible over-exploitation of $L$. digitata, the results from our study show that the risk of depletion of genetic variation and extinction should seriously be taken into account by the resource management bodies responsible for the sustainability of this marine algal crop.

Acknowledgements. This research was supported by the CNRS-INSU Coastal Ecosystem National Programme (PNEC)Baie du Mont Saint Michel, the Region Bretagne, the Bettencourt-Schueller Foundation (Coup d'élan 2001), the priority programme GDR 1002 and the European Union (BIOGAP MAST3-CT95-0019). We are particularly grateful to all who helped with collecting kelps: H. Benet, N. Bierne, I. Bonnin, H. Cabrera, C. Destombe, H. Luo, E. Martinez, O. Richard, C. Vassiliadis and M. Velmede. We also thank F. Alberto, P. Arzel, T. Guillemaud, E. Serrao, R. Streiff, F. Viard and our BIOGAP partners for their helpful comments.

\section{LITERATURE CITED}

Arzel P (1998) Les laminaires sur les côtes bretonnes. Evolution de l'exploitation et de la flottille de pêche, état actuel et perspectives, IFREMER, Plouzané

Bandeira SO, Nilsson PG (2001) Genetic population structure of the seagrass Thalassodendron ciliatum in sandy and rocky habitats in southern Mozambique. Mar Biol 139: 1007-1012

Barnay A, Ellien C, Gentil F, Thiébaut E (2003) A model on variation in larval supply: are populations of the polychaete Owenia fusiformis in the English Channel open or closed? Helgol Mar Res 56:229-237

Belkhir K, Borsa P, Goudet J, Chikhi L, Bonhomme F (1999) GENETIX, logiciel sous Windows ${ }^{\mathrm{TM}}$ pour la génétique des populations. Laboratoire Génome et Populations, CNRS UPR 9060, Université de Montpellier II, Montpellier, France

Bernardi G (2000) Barriers to gene flow in Embiotoca jacksoni, a marine fish lacking a pelagic larval stage. Evolution 54:236-237

Billot C, Rousvoal S, Estoup A, Epplen JT, Saumitou-Laprade
P, Valero M, Kloareg B (1998) Isolation and characterization of microsatellite markers in the nuclear genome of the brown alga Laminaria digitata (Phaeophyceae). Mol Ecol $7: 1778-1780$

Billot C, Boury S, Benet J, Kloareg B (1999) Development of RAPD markers for parentage analysis in Laminaria digitata. Bot Mar 42:307-314

Bohonak AJ (1999) Dispersal, gene flow, and population structure. Q Rev Biol 74:21-45

Coleman FC, Williams SL (2002) Overexploiting marine ecosystem engineers: potential consequences for biodiversity. Trends Ecol Evol 17:40-44

Cornuet JM, Piry S, Luikart G, Estoup A, Solignac M (1999) New methods employing multilocus genotypes to select or exclude populations as origins of individuals. Genetics 153:1989-2000

Coyer JA, Olsen JL, Stam WT (1997) Genetic variability and spatial separation in the sea palm kelp Postelsia palmaeformis (Phaeophyceae) as assessed with M13 fingerprints and RAPDs. J Phycol 33:561-568

Danley PD, Markert JA, Arnegard ME, Kocher TD (2000) Divergence with gene flow in the rock-dwelling cichlids of Lake Malawi. Evolution 54:1725-1737

Dayton PK (1985) Ecology of kelp communities. Annu Rev Ecol Syst 16:215-245

Duggins DO, Simenstad CA, Estes JA (1989) Magnification of secondary production by kelp detritus in coastal marine ecosystems. Science 245:170-173

Engelen AH, Olsen JL, Breeman AM, Stam WT (2001) Genetic differentiation in Sargassum polyceratium (Fucales: Phaeophyceae) around the island of Curaçao (Netherlands Antilles). Mar Biol 139:267-277

Faugeron S, Valero M, Destombe C, Martinez EA, Correa JA (2001) Hierarchical spatial structure and discriminant analysis of genetic diversity in the red alga Mazzaella laminarioides (Gigartinales). J Phycol 37:705-716

Féral JP (2001) How useful are the genetic markers in attempts to understand and manage marine biodiversity? J Exp Mar Biol Ecol 268:121-145

Goldson AJ, Hughes RN, Gliddon CJ (2001) Population genetic consequences of larval dispersal mode and hydrography: a case study with bryozoans. Mar Biol 138: 1037-1042

Goudet J (1995) FSTAT (Ver. 1.2): a computer program to calculate F-statistics. J Hered 86:485-486

Guegueniat P, Salomon JC, Wartel M, Cabioch L, Fraizier A (1993) Transfer pathways and transit time of dissolved matter in the eastern English Channel indicated by spacetime radiotracers measurement and hydrodynamic modelling. Estuar Coast Shelf Sci 36:477-494

Johnson MS, Black R (1998a) Effects of isolation by distance and geographical discontinuity on genetic subdivision of Littorina cingulata. Mar Biol 132:295-303

Johnson MS, Black R (1998b) Increased genetic divergence and reduced genetic variation in population of the snail Bembicium vittatum in isolated tidal ponds. Heredity 80: 163-172

Kain J (1979) A review of the genus Laminaria. Oceanogr Mar Biol Annu Rev 17:101-161

Kimura M, Weiss GH (1964) The stepping-stone model of population structure and the decrease of genetic correlation with distance. Genetics 49:561-576

Knowlton N, Jackson J (1993) Inbreeding and outbreeding in marine invertebrates. In: Thornhill NW (ed) The natural history of inbreeding and outbreeding. University of Chicago Press, Chicago, p 200-249

Kusumo HT, Druehl LD (2000) Variability over space and time 
in the genetic structure of the winged kelp Alaria marginata. Mar Biol 136:397-409

Kyle CJ, Boulding EG (2000) Comparative population genetic structure of marine gastropods (Littorina spp.) with and without pelagic larval dispersal. Mar Biol 137:835-845

Le Gall YE, Asensi A, Marie D, Kloareg B (1996) Parthenogenesis and apospory in the Laminariales: a flow cytometry analysis. Eur J Phycol 31:369-380

$\mathrm{Lu}$ TT, Williams SL (1994) Genetic diversity and genetic structure in the brown alga Halidrys dioica (Fucales: Cystoseiraceae) in Southern California. Mar Biol 121: 363-371

Maier I, Müller DG, Gassman G, Boland W, Jaenickz L (1988) Pheromone recepter specificity and threshold concentrations for spermatozoid release in Laminaria digitata. Naturwissenschaften 75:260-263

Miller KA, Olsen JL, Stam WT (2000) Genetic divergence correlates with morphological and ecological subdivision in the deep-water elk kelp, Pelagophycus porra (Phaeophyceae). J Phycol 36:862-870

Müller DG, Gassman G, Lüning K (1979) Isolation of a spermatozoid-releasing and -attracting substance from female gametophytes of Laminaria digitata. Nature 279: 430-431

Nei M (1978) Molecular evolutionary genetics. Columbia University Press, New York

Norton TA, Melkonian M, Andersen RA (1996) Algal biodiversity. Phycologia 35:308-326

Palumbi SR (1994) Genetic divergence, reproductive isolation, and marine speciation. Annu Rev Ecol Syst 25: 547-572

Palumbi SR, Grabowsky G, Duda T, Geyer L, Tachino N (1997) Speciation and population genetic structure in tropical Pacific Sea urchins. Evolution 51:1506-1517

Poulin E, Féral JF (1996) Why are there so many species of brooding antartic echinoids? Evolution 50:820-830

Rannala B, Mountain JL (1997) Detecting immigration by using multilocus genotypes. Proc Natl Acad Sci USA 94: 9197-9201

Raymond M, Rousset F (1995) GENEPOP (Ver. 1.2): Population genetics software for exact tests and ecumenicism. J Hered 86:248-249

Rice WR (1989) Analyzing tables of statistical tests. Evolution 43:223-225

Riginos C, Nachman MW (2001) Population subdivision in marine environments: the contributions of biogeography, geographical distance and discontinuous habitat to genetic differentiation in a blennioid fish, Axoclinus nigricaudus. Mol Ecol 10:1439-1453

Rocha-Olivares A, Vetter RD (1999) Effects of oceanographic circulation on the gene flow, genetic structure, and phylogeography of the rosenthorn rockfish (Sebastes helvomaculatus). Can J Fish Aquat Sci 56:803-813

Rousset F (1997) Genetic differentiation and estimation of gene flow from $F$-statistics under isolation by distance. Genetics 145:1219-1228

Salomon JC, Breton M (1993) An atlas of long-term currents in the Channel. Oceanol Acta 16:439-448

Santelices B (1990) Patterns of reproduction, dispersal and recruitment in seaweeds. Oceanogr Mar Biol Annu Rev 28:177-276

Sauvageau C (1916) Sur les gamétophytes de deux Laminaires. CR Acad Sci, Paris 162:601-604

Editorial responsibility: Simon Archer (Contributing Editor), Guildford, United Kingdom
Schemske DW, Husband BC, Ruckelshaus MH, Goodwillie C, Parker IM, Bishop JG (1994) Evaluating approaches to the conservation of rare and endangered plants. Ecology 75:584-606

Shaw PW, Pierce GJ, Boyle PR (1999) Subtle population structuring within a highly vagile marine invertebrate, the veined squid Loligo forbesi, demonstrated with microsatellite DNA markers. Mol Ecol 8:407-417

Shulman MJ (1998) What can population genetics tell us about dispersal and biogeographic history of coral-reef fishes? Aust J Ecol 23:216-225

Shulman MJ, Bermingham E (1995) Early life histories, ocean currents, and the population genetics of Caribbean reef fishes. Evolution 49:897-910

Slatkin M (1993) Isolation by distance in equilibrium and nonequilibrium populations. Evolution 47:264-279

Sosa PA, Lindstrom SC (1999) Isozymes in macroalgae (seaweeds): genetic differentiation, genetic variability and applications in systematics. Eur J Phycol 34:427-442

Templeton AR (1998) Nested clade analyses of phylogeographic data: testing hypotheses about gene flow and population history. Mol Ecol 7:381-397

Templeton AR, Shaw K, Routman E, Davis SK (1990) The genetic consequences of habitat framentation. Ann Mo Bot Gard 77:13-27

Thiébaut E, Dauvin JC, Lagadeuc Y (1994) Horizontal distribution and retention of Owenia fusiformis larvae (Annelida: Polychaeta) in the Bay of Seine. J Mar Biol Assoc UK 74: 129-142

Thiébaut E, Dauvin JC, Wang Z (1996) Tidal transport of Pectinaria koreni postlarvae (Annelida: Polychaeta) in the Bay of Seine (eastern English Channel). Mar Ecol Prog Ser 138:63-70

Thouin F, Gayral P, Cosson J (1983) Cartographie et étude des populations de Laminaires de Basse-Normandie. Laboratoire d'Algologie fondamentale et appliquée de l'Université de Caen

Valero M, Engel C, Billot C, Kloareg B, Destombe C (2001) Concepts and issues of population genetics in seaweeds. Cah Biol Mar 42:53-62

Walker DA, Kendrick GA (1998) Threats to macroalgal diversity: marine habitat destruction and fragmentation, pollution and introduced species. Bot Mar 41:105-112

Waples RS (1987) A multispecies approach to the analysis of gene flow in marine shore fishes. Evolution 41: $385-400$

Wares JP, Gaines SD, Cunningham CW (2001) A comparative study of asymmetric migration events across a marine biogeographic boundary. Evolution 55:295-306

Waser PM, Strobeck C (1998) Genetic signatures of interpopulation dispersal. Trends Ecol Evol 13:43-44

Weir BS, Cockerham CC (1984) Estimating F-statistics for the analysis of population structure. Evolution 38:1358-1370

Williams SL, Di Fiori RE (1996) Genetic diversity and structure in Pelvetia fastigiata (Phaephyta: Fucales): does a small effective neighborhood size explain fine-scale genetic structure? Mar Biol 126:371-382

Young A, Boyle T, Brown T (1996) The population genetic consequences of habitat fragmentation for plants. Trends Ecol Evol 11:413-418

Young AG, Brown AHD, Zach FA (1999) Genetic structure of fragmented populations of the endangered daisy Rutidosis leptorrhynchoides. Conserv Biol 13:256-265

Submitted: October 15, 2002; Accepted: February 26, 2003

Proofs received from author(s): April 22, 2003 